\title{
LY6K wt Allele
}

National Cancer Institute

\section{Source}

National Cancer Institute. LY6K wt Allele. NCI Thesaurus. Code C126133.

Human LY6K wild-type allele is located in the vicinity of $8 \mathrm{q} 24.3$ and is approximately $5 \mathrm{~kb}$ in length. This allele, which encodes lymphocyte antigen $6 \mathrm{~K}$ protein, may play a role in the regulation of cell growth. 